\title{
Increasing Profit Margins by Substituting Species in Floral Arrangements
}

\author{
Xuan (Jade) $\mathrm{Wu}^{1}$, Melinda J. Knuth ${ }^{1}$, Charles R. Hall ${ }^{1}$, \\ and Marco A. Palma ${ }^{2}$
}

ADDITIONAL INDEX WORDs. floral design, flower symmetry, online survey, willingness to pay

SUMmARY. Flower species is one of the key determinants of the aesthetic and economic value of floral products. This research study sought to evaluate whether consumer perceptions of the aesthetic appeal and monetary valuations of floral arrangements change by substituting high-cost species with low-cost species of similar appearance. In addition, the researchers explored consumer preferences for flower symmetry, which provides information to assist floral designers in choosing and using species to increase profit margins and improve the economic efficiency of the floral industry. Two experiments were administered through an online survey. For the first experiment, no difference was shown in both willingness to pay and attractiveness ratings for flowers in the high-dollar value vs. low-dollar value comparison groups. For the second experiment, roses (Rosa bybrida) were rated the highest on attractiveness, followed by dahlia (Dablia bybrida), ranunculus ( $R a$ nunculus asiaticus), and anthurium (Antburium sp.). Radial flowers were considered most appealing, followed by asymmetrical flowers, and last, bilaterally symmetrical flowers. The results of this study lend insight into how the general floral consumer does not differentiate between flower species that are similar in design features such as color, size, or symmetry. This information can be used by floral business operators to sell their bouquets at a higher margin by strategically using lower-cost flower inputs.

$\mathrm{T}$ he beauty of flowers is universally appreciated across cultures (Rihn et al., 2014). Cut flowers and floral designs have been used to mark important and meaningful holidays and occasions throughout human history (Lai and Huang, 2013). In the United States, cut flower products are commonly used for special events, to decorate homes, as gifts, and for personal uses (Kim et al., 1999; Lai and Huang, 2013; Palma and Ward 2010; Rihn et al., 2011; Yue and Hall, 2010). Cut flowers also play a critical role in the development of the U.S. economy.

Received for publication 16 July 2020. Accepted for publication 25 Sept. 2020.

Published online 21 December 2020

${ }^{1}$ Department of Horticultural Sciences, Texas A\&M University, 2133 TAMU, College Station, TX 778432124

${ }^{2}$ Department of Agricultural Economics, Texas A\&M University, 2124 TAMU College Station, TX 778432124

Funding for this study was provided by the Floral Marketing Research Fund and the Produce Marketing Association Floral Division.

X.J.W. is the corresponding author. E-mail: jadewu@ tamu.edu.

This is an open access article distributed under the CC BY-NC-ND license (https://creativecommons.org/ licenses/by-nc-nd/4.0/).

https://doi.org/10.21273/HORTTECH04695-20
The domestic cut flower market's wholesale value was $\$ 374$ million in 2018 (U.S. Department of Agriculture, 2019).

In light of intensifying competition between retail flower shops and other shopping channels due to convenience and competitive pricing, business strategies that could lower the cost of floral products but maintain the consumer value are essential. These strategies would enable flower businesses to improve competitiveness, remain profitable, and generate sustained growth in the floral market (Yeh and Huang, 2009; Yue and Behe, 2008).

Aesthetic value is a crucial element of purchasing for floral consumers, and the species of flowers greatly influences the visual impact and value of floral products (Behe et al., 1992). Previous research has investigated consumer perceptions on the aesthetic appreciation of species of flowers. In general, expensive floral products have a broader variety of flowers in the arrangement, while lower-priced products have more limited variety (Behe et al., 1992). Vierheilig and Alvensleben (1986, 1988) demonstrated that attitudes toward aesthetically appealing flower species vary across generations. Younger German consumers prefer flowers with a natural look, whereas more mature consumers prefer flowers that look expensive. Earlier research performed by Hutchison and Robertson (1979) indicated that mixed floral arrangements with carnations (Dianthus caryophyllus) and chrysanthemums (Chrysanthemum sp.) are more preferred than those with roses (Rosa hybrida) only. Kelley et al. (2002) found that consumers value the addition of edible flower species more than they do additional flower colors and that consumers prefer multispecies choices above the single species. These findings are supported by consumer research regarding container garden preferences (Mason et al., 2008), which also showed consumer preferences for multispecies. Baourakis et al. (2000) suggested that consumers value more diverse species when buying flowers for personal use than when buying for gift-giving.

Similar to the symmetry of the overall floral design, flower symmetry refers to whether and how a flower can be divided into identical or mirror-image pairs of itself with a central axis (Almeida and Galego, 2005; Butler et al., 2005; Johnson et al., 2001). The most common types of symmetry in nature are bilateral, radial, and asymmetrical. Bilateral flowers can only be divided by a single axis into two mirror-image halves, similar to human faces, whereas radial flowers can be divided into more than three identical parts rotating around the center (Almeida and Galego, 2005; Butler et al., 2005; Johnson et al., 2001). Some flowers, however, may have no axis of symmetry at all and are called asymmetrical flowers (Weberling, 1992).

A number of studies have investigated preferences relative to the symmetry of objects, including flowers. Hula and Flegr (2016) reported preferences for multiaxes objects over single or biaxis objects. Some studies found the most recognizable items are most appreciated and easily processed by the human brain, such as symmetrical objects (Enquist and Arak, 1994; Enquist and Johnstone, 1997; Jacobsen and Hofel, 2002; Jacobsen et al., 2006; Leder et al., 2004). Studies have 
shown that moderately complex objects are most preferred over those with very low or very high complexity because very low complexity is considered "boring," whereas very high complexity is considered "confusing and hard to process" (Akalin et al., 2009; Hekkert and Wieringen, 1990; Reber et al., 2004). The length of time required to process degrees of attractiveness is correlated with the complexity of an object's axes of symmetry (Evans et al., 2000; Tinio and Leder, 2009). Although some researchers claimed humans have an inherent preference for bilaterally symmetrical flowers, Evans et al. (2000) found radially symmetrical flowers are more preferred than bilaterally symmetrical flowers (Little and Jones, 2003). Hula and Flegr (2016) found radial symmetry and sharp contours are more appealing in flower selection. Many studies suggested humans also prefer round objects over sharp, pointed objects (Bar and Neta, 2006; Leder et al., 2011; Silvia and Barona, 2009; Westerman et al., 2012). Some studies indicated this is a temporary fashion and hypothesized sharp objects could evoke strong feelings (Carbon, 2010). These feelings could be related to feelings of mystery and power, and may be aesthetically pleasing (Coss, 2003).

Even though previous studies have investigated consumer perceptions of species of plants and aesthetics of symmetry, there is no research on whether and how the substitution of species (of differing value) affect consumer perceptions and their valuation of the aesthetic and economic value of floral arrangements. In this study, the researchers explored whether and how consumer likability and willingness to pay for floral arrangements change when high-cost flowers were substituted with lower-cost flowers of a similar color and appearance. The researchers also examined whether consumers had a preference for a particular flower symmetry among the three common symmetry types, including bilateral, radial, and asymmetric.

\section{Materials and methods}

This research was conducted with an online survey (Qualtrics, Provo, UT). Online surveys are often preferred to traditional mail or in- person survey methods due to their convenience, speed, and affordability (Evans and Mathur, 2005).

The instrument included questions regarding species substitution, open-ended willingness to pay questions (Figs. 1 and 2), and five-point Likert scale-rating questions (Likert, 1932) (Figs. 3 and 4). A Likert scale was used to measure the subjects' level of agreement with a statement (VanDerZanden et al., 2008). For the willingness to pay questions, subjects were asked: "How much would you be willing to pay for this arrangement?" A floral design photograph was shown to the subjects under each question. The subjects were asked to type a dollar value in the text box. The content validation was set to be numbers only from 0 to 250 and a two decimal maximum. To rate attractiveness, the subjects were asked to express their agreement of the question, "Is this floral arrangement aesthetically appealing to you?" on a fivepoint Likert scale where $1=$ strongly disagree and $\mathbf{5}=$ strongly agree.

The survey subjects were divided into two between-subject treatments. One group could only see and rate bouquets with high-cost species, and the other could only see and rate those with the substituted low-cost species. Ten species were used in total: five expensive species and five inexpensive species. The average cost for five expensive species was

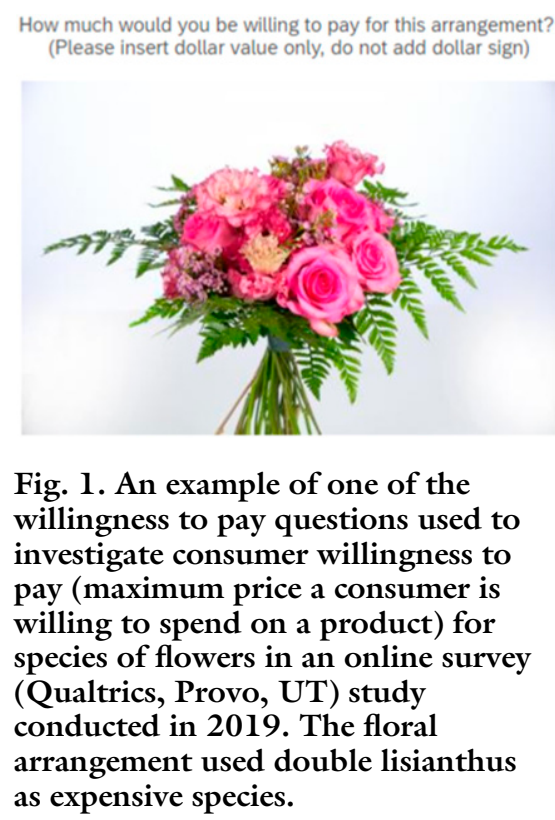

$\$ 2.84$ per stem, and that of the five inexpensive species was $\$ 0.85$ per stem. Five stems of expensive species were substituted with inexpensive species in each design set. Monochromatic color harmony was applied for all the bouquets in this study and bouquets with both expensive and inexpensive species were considered as mixed-species. The bouquets with only inexpensive species were considered monospecies.

The hand-tied bouquet was chosen for the experiment, as it is the most common style in the market (Behe and Wolnick, 1991). Roses, carnations, chrysanthemums, and alstroemeria (Alstroemeria aurea) were chosen as the less expensive species because they were the four most imported and recognizable species due to their popularity in world cut flower trade in 2019 (Loyola et al., 2019; U.S. Department of Agriculture, 2020). Roses were used as the substitute for double lisianthus (Eustoma grandiflorum), which cost more than twice as much as a regular rose ( $\$ 2.40$ vs. $\$ 1.15$ per stem) ( $\mathrm{Ta}-$ ble 1). Roses (when substituted for double lisianthus) cost $\approx \$ 5.75$ per arrangement (five stems) vs. $\$ 12.00$ for double lisianthus (five stems). Carnation was the inexpensive species substitute for ranunculus (Ranunculus asiaticus), as they are both round, and have many layers of petals. The

How much would you be willing to pay for this arrangement? (Please insert dollar value only, do not add dollar sign)

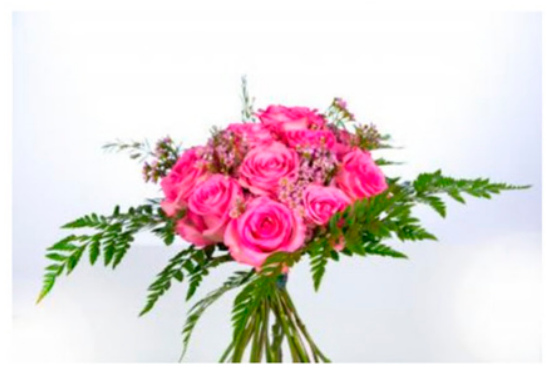

Fig. 2. An example of one of the willingness to pay questions used to investigate consumer willingness to pay (maximum price a consumer is willing to spend on a product) for species of flowers in an online survey (Qualtrics, Provo, UT) study conducted in 2019. The floral arrangement used five stems of roses as inexpensive species to substitute for five stems of expensive species double lisianthus. 


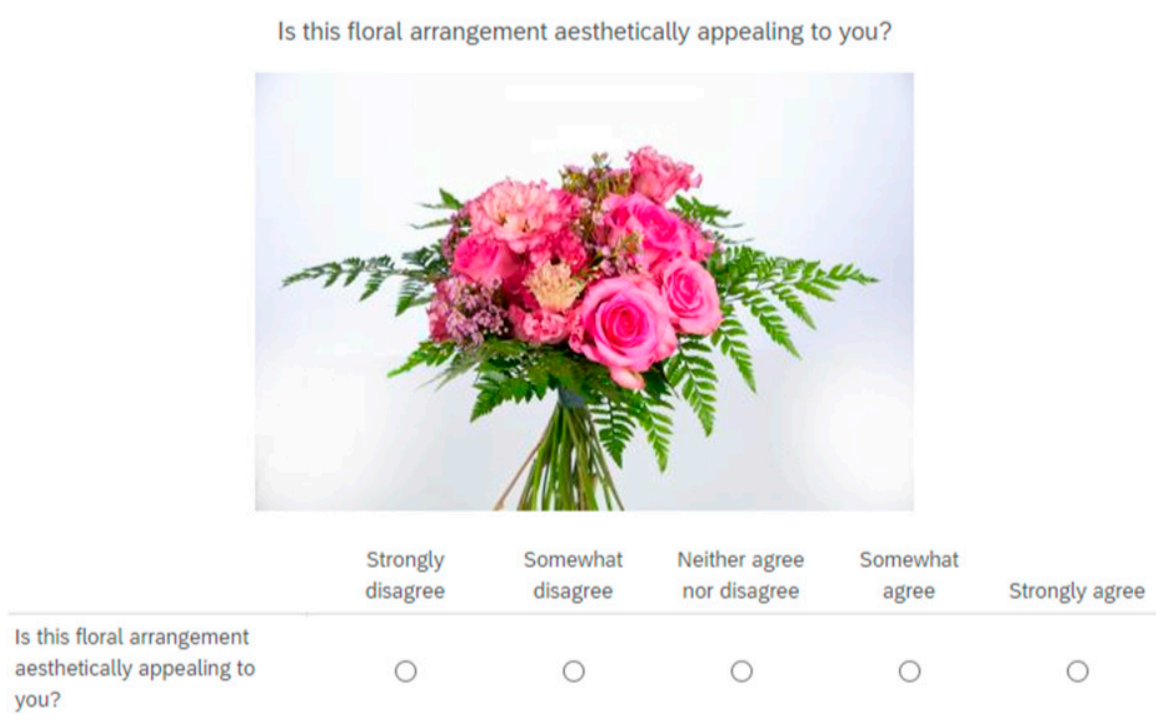

Fig. 3. An example of one of the five-point Likert scale questions used to investigate consumer attractiveness ratings of species of flowers in an online survey (Qualtrics, Provo, UT) study conducted in 2019. The floral arrangement used double lisianthus as expensive species.

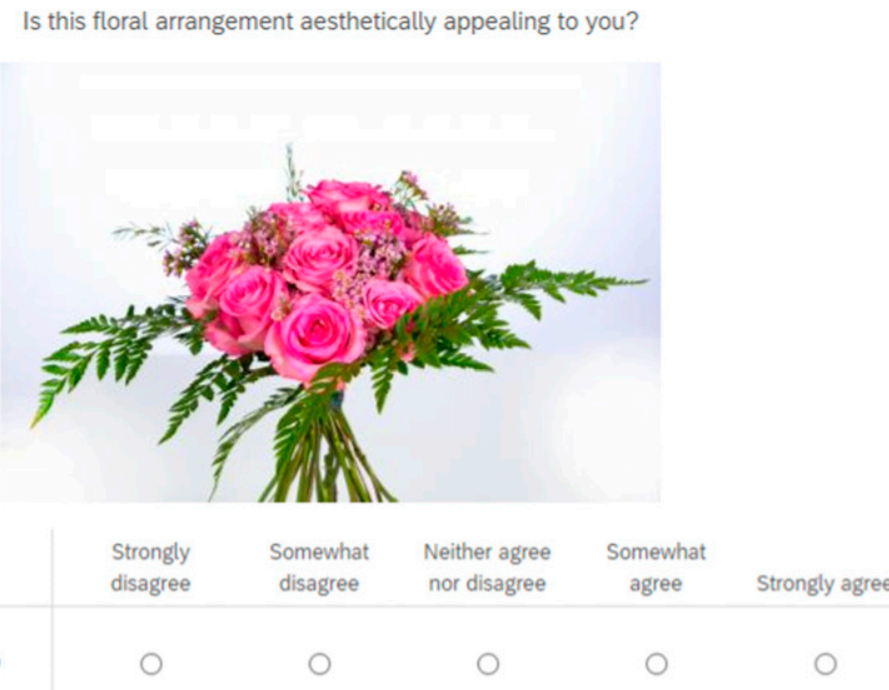

Is this floral arrangement aesthetically appealing to you?

Fig. 4. An example of one of the five-point Likert scale questions used to investigate consumer attractiveness ratings of species of flowers in an online survey (Qualtrics, Provo, UT) study conducted in 2019. The floral arrangement used five stems of roses as inexpensive species to substitute for five stems of expensive species double lisianthus.

wholesale price was $\$ 0.49$ per stem for carnation, and $\$ 1.83$ per stem for ranunculus (Table 1). Carnations (when substituted for ranunculus) cost $\approx \$ 2.45$ per arrangement (five stems) vs. $\$ 9.15$ (five stems) for ranunculus. Football chrysanthemum (Chrysanthemum morifolium) was the inexpensive species substituted for dahlia (Dablia bybrida). The wholesale price of football chrysanthemum is $\approx \$ 1.10$ per stem, as (five stems) vs. \$12.50 for nerine (five stems). These prices were the actual price offerings for the flower species purchased for the study from a wholesale floral firm (Westside Flower Exchange, Houston, TX).

The second major part of the survey included eight questions for the individual flower symmetry experiment. The question "Is this flower aesthetically appealing to you?" was used to assess the attractiveness of each of the eight flowers (Fig. 5). The subjects were asked to express their agreement of the question on a five-point Likert scale where $1=$ strongly disagree and $5=$ strongly agree. The color within the photographs was removed, and the photographs were converted to the same size to avoid any possible effect of color or size on the attractiveness ratings. The size $(400 \times 266$ pixels $)$ and resolution (96 pixels) of the photographs were optimized for maintaining high-quality displays of flowers so that participants could clearly identify and compare different species. The size of the flowers in the photographs was kept close to the actual size of real flowers. The order of the questions was randomized to avoid ordering effect. A total of eight flowers were investigated in the second experiment. Two bilaterally symmetrical flowers were chosen, including anthurium (Anthurium sp.) and phalaenopsis orchid (Phalaenopsis amabilis). Four radially symmetrical flowers were chosen, including dahlia, rose, ranunculus, and daisy pompon chrysanthemum ( $C$. morifolium). Last, two asymmetrical flowers were chosen, including calla lily (Zantedeschia aethiopica) and bird of paradise (Strelitzia reginae).

To gain a randomized sample pool, the researchers contracted $\mathrm{Me}$ chanical Turk (Amazon, Seattle, WA), which maintains a "worker pool" of $\approx 250,000$ persons and has control mechanisms in place to eliminate duplicate workers. The researchers specified within the invitation that individuals had to be at least 18 years old and must reside within the United States. Invitations were distributed from 16 to $25 \mathrm{Aug}$. 2019. Subjects were directed to answer four quality assurance checkpoints to ensure that respondents' attention was at a high level throughout the entire survey to the answers 
Table 1. Wholesale prices of expensive species versus inexpensive species used for floral arrangements in an online survey (Qualtrics, Provo, UT) conducted in 2019. ${ }^{\mathrm{z}}$

\begin{tabular}{|c|c|c|c|c|}
\hline & $\begin{array}{l}\text { Wholesale } \\
\text { price per } \\
\text { stem }\end{array}$ & $\begin{array}{c}\text { Wholesale } \\
\text { price difference } \\
\text { per stem }\end{array}$ & $\begin{array}{l}\text { Wholesale } \\
\text { price for } \\
\text { five stems }\end{array}$ & $\begin{array}{l}\text { Wholesale price } \\
\text { difference for } \\
\text { five stems }\end{array}$ \\
\hline Species & \multicolumn{4}{|c|}{$(\$)$} \\
\hline & \multicolumn{4}{|c|}{ Lisianthus vs. rose } \\
\hline Lisianthus & 2.40 & 1.25 & 12.00 & 6.25 \\
\hline \multirow[t]{2}{*}{ Rose } & 1.15 & & 5.75 & \\
\hline & \multicolumn{4}{|c|}{ Ranunculus vs. carnation } \\
\hline Ranunculus & 1.83 & 1.34 & 9.15 & 6.70 \\
\hline \multirow[t]{2}{*}{ Carnation } & 0.49 & & 2.45 & \\
\hline & \multicolumn{4}{|c|}{ Dahlia vs. football chrysanthemum } \\
\hline Dahlia & 4.64 & 3.54 & 23.20 & 17.70 \\
\hline \multirow{2}{*}{$\begin{array}{l}\text { Football } \\
\text { chrysanthemum }\end{array}$} & 1.10 & & 5.50 & \\
\hline & \multicolumn{4}{|c|}{ Nerine vs. alstroemeria } \\
\hline Nerine & 2.50 & 1.83 & 12.50 & 9.15 \\
\hline Alstroemeria & 0.67 & & 3.35 & \\
\hline
\end{tabular}

${ }^{\mathrm{z}}$ These prices were the actual price offerings for the flower species purchased for the study from a wholesale floral firm (Westside Flower Exchange, Houston, TX).

Is this flower aesthetically appealing to you?
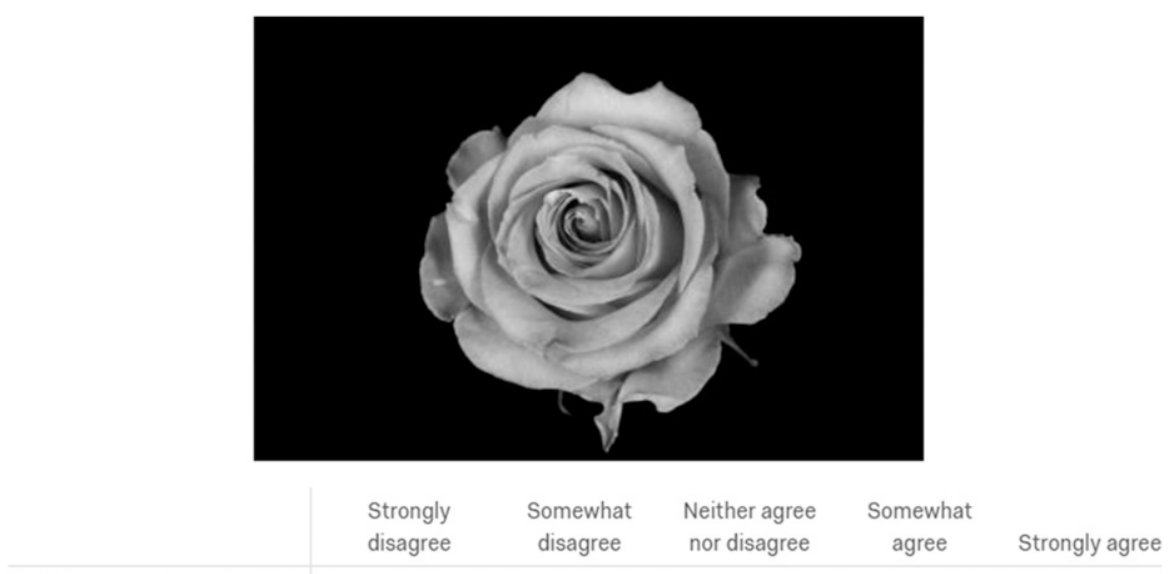

Is this flower aesthetically

appealing to you?

Fig. 5. An example of one of the five-point Likert scale questions used to investigate consumer attractiveness ratings of individual flowers in an online survey (Qualtrics, Provo, UT) study conducted in 2019.

they provided. To prevent false hypothesis rejection, an ex-ante power analysis indicated the study required at least 128 responses.

Statistical software (JMP version 14; SAS Institute, Cary, NC) was used to conduct a series of Student $t$ test differences in willingness to pay for the design sets. Student $t$ tests and Wilcoxon rank-sum tests were used to compare Likert scale ratings between the high and low-cost species. The Wilcoxon rank-sum tests and Tukey's range tests were applied to compare Likert scale ratings in the individual flower symmetry experiment and mean comparisons.

\section{Results and discussion}

A Cronbach's alpha reliability analysis showed the overall survey instrument to have good reliability $(\alpha=$ $0.778)$. According to Tavakol and Dennick (2011), a value greater than 0.70 is considered an acceptable level of internal consistency.

\section{Demographic characteristics}

A total of 131 participants passed the quality assurance checks and completed our survey. Demographic characteristics including gender, age, education, annual income, race, and frequency of cut flower purchase are presented in Table 2. Approximately $53.4 \%$ of the participants were female. The largest age group was 18 to 34 years old, which accounted for $38.2 \%$ of the participants followed by subjects who were 35 to 44 years old $(31.3 \%)$. Forty-five to 54 years of age accounted for $14.5 \%, 55$ to 64 years $(13.0 \%)$, and 65 to 74 years $(3.0 \%)$. The distribution of education level was high school or professional certification (12.2\%), associate degree $(45.0 \%)$, bachelor's degree $(34.4 \%)$, and graduate degree $(8.4 \%)$. Survey participants who made $\$ 30,000$ to $\$ 49,999$ represented $30.5 \%$ of the sample followed by those who made $\$ 50,000$ to $\$ 69,999$ per year (26.7\%). Approximately 22.2\% of the participants had an annual income of less than $\$ 30,000,7.6 \%$ had an income of $\$ 70,000$ to $\$ 89,999$ and $13.0 \%$ had an income of more than $\$ 90,000$. The vast majority of the participants were "White" (83.2\%) followed by "Asian" $(8.4 \%)$ and "African American or Black" (6.1\%). As for the frequency of flower purchase, people who purchased flowers a few times yearly were the largest group, accounting for $67.9 \%$ of the sample. Participants who purchased flowers a few times weekly or monthly made up $9.2 \%$ of the sample, and those who never purchase flowers were $22.9 \%$ of the sample. The demographics of the sample covered general floral consumers according to previous studies (Rihn et al., 2011; Yue and Behe, 2008; Yue and Hall, 2010).

Expt. 1: Substitution. Sixtynine subjects rated bouquets designed using expensive species, and 62 subjects rated the bouquets designed using inexpensive species. For each of the comparisons, double lisianthus and rose, ranunculus and carnation, dahlia and football chrysanthemum, and nerine and alstroemeria, no differences were found either in the mean willingness to pay, or attractiveness ratings (Tables 3 and 4 ). The subjects rated each of the inexpensive bouquets equal in value and attractiveness to the expensive bouquets. As no difference was shown in either willingness to pay or attractiveness ratings for any of the expensive and inexpensive species 
Table 2. Sociodemographic characteristics of respondents to an online survey (Qualtrics, Provo, UT) in 2019 evaluating consumer preferences and willingness to pay (maximum price a consumer is willing to spend on a product) for floral arrangements with expensive species versus inexpensive species and symmetry of flowers $(n=131)$.

\begin{tabular}{|c|c|c|c|}
\hline \multicolumn{2}{|c|}{ Demographic category } & $\begin{array}{l}\text { Respondents } \\
\text { (no.) }\end{array}$ & $\begin{array}{l}\text { Proportion of } \\
\text { respondents (\%) }\end{array}$ \\
\hline \multirow[t]{2}{*}{ Gender } & Male & 60 & 45.8 \\
\hline & Female & 71 & 54.2 \\
\hline \multirow[t]{5}{*}{ Age (years) } & $18-34$ & 50 & 38.2 \\
\hline & $35-44$ & 41 & 31.3 \\
\hline & $45-54$ & 19 & 14.5 \\
\hline & $55-64$ & 17 & 13.0 \\
\hline & $65-74$ & 4 & 3.0 \\
\hline \multirow[t]{4}{*}{ Education } & $\begin{array}{l}\text { High school or professional } \\
\text { certification }\end{array}$ & 16 & 12.2 \\
\hline & Associates degree & 59 & 45.0 \\
\hline & Bachelor's degree & 45 & 34.4 \\
\hline & Graduate degree & 11 & 8.4 \\
\hline \multirow[t]{5}{*}{ Annual income } & Less than $\$ 30,000$ & 29 & 22.2 \\
\hline & $\$ 30,000-\$ 49,999$ & 40 & 30.5 \\
\hline & $\$ 50,000-\$ 69,999$ & 35 & 26.7 \\
\hline & $\$ 70,000-\$ 89,999$ & 10 & 7.6 \\
\hline & More than $\$ 90,000$ & 17 & 13.0 \\
\hline \multirow[t]{4}{*}{ Race } & Asian & 11 & 8.4 \\
\hline & African American or Black & 8 & 6.1 \\
\hline & White & 109 & 83.2 \\
\hline & Other & 3 & 2.3 \\
\hline \multirow{3}{*}{$\begin{array}{l}\text { Frequency of } \\
\text { flower } \\
\text { purchase }\end{array}$} & Few times weekly or monthly & 12 & 9.2 \\
\hline & Few times yearly & 89 & 67.9 \\
\hline & Never & 30 & 22.9 \\
\hline
\end{tabular}

Table 3. Mean comparisons of willingness to pay (maximum price a consumer is willing to spend on a product) for floral arrangements with expensive species versus inexpensive species of respondents to an online survey (Qualtrics, Provo, $\mathrm{UT})$ in $2019(\mathrm{n}=131)$.

\begin{tabular}{|c|c|c|c|c|c|}
\hline \multirow[b]{3}{*}{ Species } & \multicolumn{3}{|c|}{ Willingness to pay } & \multirow{2}{*}{\multicolumn{2}{|c|}{$t$ test $^{\mathrm{z}}$}} \\
\hline & Mean & SD & $\overline{\text { Range }}$ & & \\
\hline & \multicolumn{3}{|c|}{$(\$)$} & $t$ & $P$ \\
\hline & \multicolumn{5}{|c|}{ Lisianthus vs. rose } \\
\hline Lisianthus $(n=69)$ & $26.507^{y}$ & 16.002 & $0-90$ & -1.203 & 0.231 \\
\hline \multirow{2}{*}{ Rose $(n=62)$} & 29.903 & 16.255 & $7-98$ & & \\
\hline & \multicolumn{5}{|c|}{ Ranunculus vs. carnation } \\
\hline Ranunculus $(\mathrm{n}=69)$ & 26.927 & 17.206 & $0-85$ & -0.342 & 0.733 \\
\hline \multirow[t]{2}{*}{ Carnation $(n=62)$} & 27.935 & 16.538 & $0-75$ & & \\
\hline & \multicolumn{5}{|c|}{ Dahlia vs. football chrysanthemum } \\
\hline Dahlia $(\mathrm{n}=69)$ & 21.862 & 14.081 & $0-80$ & -1.534 & 0.128 \\
\hline Football chrysanthemum $(\mathrm{n}=62)$ & 26.500 & 19.705 & $1-120$ & & \\
\hline & \multicolumn{5}{|c|}{ Nerine vs. alstroemeria } \\
\hline Nerine $(n=69)$ & 29.217 & 18.147 & $0-101$ & -1.079 & 0.283 \\
\hline Alstroemeria $(\mathrm{n}=62)$ & 32.629 & 17.998 & $6-100$ & & \\
\hline
\end{tabular}

${ }^{\mathrm{z}}$ Analyses were generated using JMP software (version 14; SAS Institute, Cary, NC).

y The willingness to pay questions asked subjects: "How much would you be willing to pay for this arrangement?" A floral design photograph was shown to the subjects under each question. The subjects were asked to type a dollar value in the text box.

comparison group, the expensive species could be substituted with less expensive species to reduce input costs and increase profit margins.
Consumers also valued monospecies and mixed-species bouquets equally in selected floral arrangements. Earlier literature reported that consumers are willing to pay higher premiums for mixed-species arrangements than single-species arrangements (Kelley et al., 2002; Mason et al., 2008; Rihn et al., 2014). No differences in attractiveness ratings were seen in our study between mixed-species and monospecies arrangements, which may be partially explained by our use of the same-color flowers for all species, which may have reduced the aesthetic differentiation to some extent compared with multicolor floral arrangements.

Previously in the floral industry, experts have anecdotally believed that consumers can visually see the difference between flower species. Holding color, shape, and size constant, the results of this survey indicated that the general consumers are insensitive to the differences. This may be encouraging for some within the floral industry, yet disheartening for others. According to our findings, floral firms can gain a higher profit margin by mixing lower-cost flowers into highercost designs, without sacrificing attractiveness.

Expt. 2: Symmetry. Tukey's range tests revealed that the perceived beauty of roses was rated the highest $($ mean $=4.36)$, followed by dahlia $($ mean $=3.84)$, and third, ranunculus $($ mean $=3.82)($ Table 5$)$. These three flowers are radially symmetrical flowers. The bilaterally symmetrical flower anthurium was the least preferred $($ mean $=2.56)$.

The mean separation of three flower symmetry types indicated that radially symmetrical flowers were the most preferred $($ mean $=3.77)$, followed by asymmetrical flowers $($ mean $=3.19)$, and, last, bilateral flowers $($ mean $=2.92)$ (Table 6). Round and radial flowers, most commonly seen in nature (Hula and Flegr, 2016), are considered to be easily recognizable and the most aesthetically appealing. Cultural influence may also explain why roses have the highest perceived aesthetic value, as rose is the national flower of the United States, bestowing on it a symbolic value for Americans (National Rose Garden, 2020). Subjects rated the beauty of the bilaterally symmetrical flowers as less attractive than radial symmetry flowers.

These results are consistent with previous studies. Radial flowers are considered most appealing, which may be due to the ease with processing, and 
Table 4. Mean comparisons of beauty ratings for floral arrangements with expensive species and inexpensive species of respondents to an online survey (Qualtrics, Provo, UT) in $2019(\mathrm{n}=131) .^{\mathrm{z}}$

\begin{tabular}{|c|c|c|c|c|c|c|}
\hline \multirow[b]{2}{*}{ Species } & \multirow[b]{2}{*}{ Mean } & \multirow[b]{2}{*}{ SD } & \multicolumn{2}{|c|}{$t$ test $^{\mathrm{y}}$} & \multicolumn{2}{|c|}{$\begin{array}{l}\text { Wilcoxon } \\
\text { rank-sum test }\end{array}$} \\
\hline & & & $t$ & $P$ & $Z$ & $P$ \\
\hline & \multicolumn{6}{|c|}{ Lisianthus vs. rose } \\
\hline Lisianthus $(\mathrm{n}=69)$ & $4.044^{\mathrm{y}}$ & 1.021 & -1.764 & 0.080 & 1.547 & 0.122 \\
\hline Rose $(n=62)$ & 4.323 & 0.785 & & & & \\
\hline & \multicolumn{6}{|c|}{ Ranunculus vs. carnation } \\
\hline Ranunculus $(\mathrm{n}=69)$ & 3.609 & 1.140 & -0.658 & 0.512 & 0.767 & 0.442 \\
\hline Carnation $(n=62)$ & 3.742 & 1.173 & & & & \\
\hline & \multicolumn{6}{|c|}{ Dahlia vs. football chrysanthemum } \\
\hline Dahlia $(\mathrm{n}=69)$ & 3.681 & 1.105 & 0.184 & 0.855 & -0.071 & 0.944 \\
\hline Football chrysanthemum $(\mathrm{n}=62)$ & 3.645 & 1.132 & & & & \\
\hline & \multicolumn{6}{|c|}{ Nerine vs. alstroemeria } \\
\hline Nerine $(n=69)$ & 4.073 & 0.880 & 0.516 & 0.283 & -0.120 & 0.905 \\
\hline Alstroemeria $(\mathrm{n}=62)$ & 3.984 & 1.963 & & & & \\
\hline
\end{tabular}

${ }^{\mathrm{z}}$ Subjects were asked to express their agreement of the question, "Is this floral arrangement aesthetically appealing to you?" on a five-point Likert scale where $1=$ strongly disagree, $2=$ somewhat disagree, $3=$ neither agree nor disagree, $4=$ somewhat agree, and $5=$ strongly agree

${ }^{\mathrm{y}}$ Analyses were generated using JMP software (version 14; SAS Institute, Cary, NC).

Table 5. Mean comparisons of beauty ratings for individual flowers with bilateral, radial symmetry and asymmetrical flowers by respondents to an online survey (Qualtrics, Provo, UT) in $2019(\mathrm{n}=131)^{\mathrm{z}}$

\begin{tabular}{llccc}
\hline Species $^{\mathrm{y}}$ & Mean & SD & F & P \\
\hline Rose & $4.359 \mathrm{a}^{\mathrm{x}}$ & 0.929 & 30.414 & $<0.0001$ \\
Dahlia & $3.840 \mathrm{~b}$ & 1.128 & & \\
Ranunculus & $3.824 \mathrm{~b}$ & 1.212 & & \\
Calla lily & $3.450 \mathrm{bc}$ & 1.204 & & \\
Phalaenopsis orchid & $3.275 \mathrm{~cd}$ & 1.336 & & \\
Chrysanthemum & $3.000 \mathrm{cde}$ & 1.203 & & \\
Bird of paradise & $2.924 \mathrm{de}$ & 1.334 & & \\
Anthurium & $2.565 \mathrm{e}$ & 1.313 & & \\
\hline
\end{tabular}

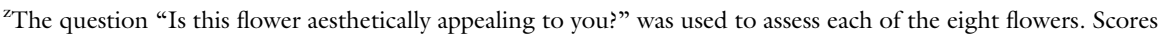
were based on a five-point Likert scale where $1=$ strongly disagree, $2=$ somewhat disagree, $3=$ neither agree nor disagree, $4=$ somewhat agree, and $5=$ strongly agree.

y Rose, dahlia, ranunculus, and chrysanthemum are radial flowers, which can be divided into more than three identical parts rotating around the center (Almeida and Galego, 2005; Butler et al., 2005; Johnson et al., 2001). Calla lily and bird of paradise are asymmetrical flowers, which have no axis of symmetry (Weberling, 1992). Phalaenopsis orchid and anthurium are bilateral flowers, which can only be divided by a single axis into two mirrorimage halves (Almeida and Galego, 2005; Butler et al., 2005; Johnson et al., 2001).

${ }^{\mathrm{x}}$ Different letters indicate significant differences among species $(P<0.05)$. Analyses were generated using Tukey's range test with JMP software (JMP version 14; SAS Institute, Cary, NC).

Table 6. Mean comparisons of beauty ratings for three flower symmetry types (radial, asymmetrical, and bilateral) by respondents to an online survey (Qualtrics, Provo, UT) in $2019(\mathrm{n}=131) .^{\mathrm{z}}$

\begin{tabular}{lccccc}
\hline Species $^{\mathrm{y}}$ & Observations (no.) & Mean & SD & F & $P$ \\
\hline Radial & 655 & $3.773 \mathrm{a}^{\mathrm{x}}$ & 1.295 & 49.742 & $<0.0001$ \\
Asymmetrical & 262 & $3.187 \mathrm{~b}$ & 1.371 & & \\
Bilateral & 262 & $2.923 \mathrm{c}$ & 1.203 & & \\
\hline
\end{tabular}

${ }^{\mathrm{z}} \mathrm{S}$ cores were based on a five-point Likert scale where $\mathrm{l}=$ strongly disagree, 2 = somewhat disagree, $3=$ neither agree nor disagree, $4=$ somewhat agree, and $5=$ strongly agree.

${ }^{y}$ Radial flowers can be divided into more than three identical parts rotating around the center (Almeida and Galego, 2005; Butler et al., 2005; Johnson et al., 2001). Asymmetrical flowers have no axis of symmetry (Weberling, 1992). Bilateral flowers can only be divided by a single axis into two mirror-image halves (Almeida and Galego, 2005; Butler et al., 2005; Johnson et al., 2001).

${ }^{\mathrm{x}}$ Different letters indicate significant differences $(P<0.05)$. Analyses were generated using Tukey's range test with JMP software (JMP version 14; SAS Institute, Cary, NC). peoples' preference for round objects over objects with sharp contours (Bar and Neta, 2006; Leder et al., 2011; Silvia and Barona, 2009; Westerman et al., 2012). Radially symmetrical flowers have the most axes compared with the other two symmetry groups in this experiment. The processing time shortens, and the preference increases with the increase in an object's axes of symmetry (Evans et al., 2000; Hula and Flegr, 2016; Tinio and Leder, 2009). Bilaterally symmetrical flowers had the lowest beauty rating. Bilateral flowers are less common and are generally perceived as difficult to recognize and categorize, resulting in their low attractiveness ratings (Hula and Flegr, 2016). Some subjects may perceive bilateral flowers as bizarre (Hula and Flegr, 2016), which could explain why bilateral symmetry was the least preferred in our study.

\section{Conclusions}

Arranged flowers represent the largest product segment in the industry and attract a premium compared with unarranged flowers. These products are sold mostly at retail flower shops, requiring specialized knowledge, skills, and creativity to make, and are sensitive to consumer sentiment (IBISWorld, 2019).

Some strategies to increase the perceived value of floral products include creative application of decorative/trendy accessories, and materials that are not normally used in floral designs to increase the novelty and uniqueness of designs; pairing flowers with other products such as chocolate, wine, jewelry, and books (Lai and Huang, 2013; Rihn et al., 2011); labeling production process of flowers, origin, longevity guarantee, and certification (Rihn et al., 2016; Rombach et al., 2018); or using aesthetically pleasing containers and packaging (American Floral Endowment, 2016; Huang, 2007; Yue and Hall, 2010).

There are some limitations of our study that future research can potentially explore and address. First, the subjects rated floral arrangements and individual flowers only by viewing photographs. Different results may have been generated if the experiment was conducted in person instead of online, which would cause more sensory experience and emotional arousal, and thus affect the 
attractiveness ratings of floral arrangements and individual flowers (Yeh and Huang, 2009). The color of the photographs for studying individual flower symmetry was removed to investigate purely the shape of the flowers and avoid color effects on consumer preferences and beauty ratings. Future studies could compare and contrast the differences in using photographs with and without colors.

Second, the sample size of this study is limited based on Krejcie and Morgan (1970), who recommended a sample size of 382 for a population size of more than 75,000. A most recent study (Robinson et al., 2019) indicated the Amazon Mechanical Turk panel, where our survey was distributed, have at least 250,810 workers worldwide and 226,500 workers in the United States. There were $\approx 80,000-85,000$ active workers per year from 2016 to 2018 (Robinson et al., 2019). Accordingly, the researchers can surmise that the generalizability of the results is constrained by the sample frame limitation.

Another limitation of our study is the limited number of flower species investigated. There are four comparison groups in the species substitution experiment and eight species in the flower symmetry experiment. Investigations into more flower species would increase the accuracy of the overall aesthetic value consumers place on flower species and symmetry types. As this study is the first study exploring consumer perception change toward substitution of flower species in the floral arrangements, the researchers limited the design style to the most commonly seen, hand-tied bouquets. Future studies could investigate the uses of flowers in other design styles. Last, other factors may influence consumer preferences and beauty ratings of flower symmetry, such as emotional connection and personal preference based on life experience. Future research could explore what roles these factors play in consumer purchasing behavior.

In summary, flower species is a key determinant of the aesthetic and economic value of floral products. Yet, evaluating species of greater dollar value vs. lesser dollar value has not been researched to date. The researchers sought to fill that information gap. By doing so, the researchers found that consumers are insensitive to species that cost more and perceive flowers to be of similar beauty. Therefore, this research provides important information regarding the value consumers place on flower species, both at the floral arrangement level and individual flower level. This information could potentially assist industry firms in the strategic selection and uses of flowers in the floral arrangements to lower the final cost of floral products and increase profit margins.

\section{Literature cited}

Akalin, A., K. Yildirim, C. Wilson, and O. Kilicoglu. 2009. Architecture and engineering students' evaluations of house facades: Preference, complexity and impressiveness. J. Environ. Psychol. 29:124132, doi: 10.1016/j.jenvp.2008.05.005.

Almeida, J. and L. Galego. 2005. Flower symmetry and shape in antirrhinum. Intl. J. Dev. Biol. 49:527-537, doi: 10.1387/ ijdb.041967ja.

American Floral Endowment. 2016. 2016 Generations of Flowers Study. 1 Sept. 2020. <https://endowment.org/ generationsstudy $/>$

Baourakis, G., D. Gerasopoulos, N. Kalofolias, N. Kalogeras, and A. Zoumis. 2000. Marketing research: The case of loral products. Acta Hort. 541:227-232, doi: 10.17660/ActaHortic.2000.541.32.

Bar, M. and M. Neta. 2006. Humans prefer curved visual objects. Psychol. Sci. 17:645-648, doi: 10.1111/j.14679280.2006.01759.x.

Behe, B.K., T.A. Price, and H.K. Tayama. 1992. Analysis of consumer purchases of floral products in supermarkets. HortScience 27:455-459, doi: 10.21273/ HORTSCI.27.5.455.

Behe, B.K. and D.J. Wolnick. 1991. Type of floral product purchased and demographic characteristics and floral knowledge of consumers. HortScience 26:414-416, doi: 10.21273/HORTSCI.26.4.414.

Butler, S., J. DelPrince, C. Fowler, H. Gilliam, J.L. Johnson, W.L. McKinley, H. Money-Collins, L.L. Moss, P. Murray, K. Pamper, and P.D. Scace. 2005. The AIFD guide to floral design. Intelvid Group, Flourtown, PA.

Carbon, C.C. 2010. The cycle of preference: Long-term dynamics of aesthetic appreciation. Acta Psychol. 134:233-244, doi: 10.1016/j.actpsy.2010.02.004.

Coss, R.G. 2003. The role of evolved perceptual biases in art and design, p. 69-130.
In: E. Voland and K. Grammer (eds.). Evolutionary aesthetics. Springer, Berlin, Germany.

Enquist, M. and A. Arak. 1994. Symmetry, beauty and evolution. Nature 372: 169-172.

Enquist, M. and R.A. Johnstone. 1997. Generalization and the evolution of symmetry preferences. Proc. R. Soc. Lond. B Biol. Sci. 264:1345-1348, doi: 10.1098/ rspb.1997.0186.

Evans, C.S., P. Wenderoth, and K. Cheng. 2000. Detection of bilateral symmetry in complex biological images. Perception 29:31-42, doi: 10.1068/p2905.

Evans, J. and A. Mathur. 2005. The value of online surveys. Internet Res. 15:195219, doi: 10.1108/10662240510590360.

Hekkert, P. and P.C.W. Wieringen. 1990. Complexity and prototypicality as determinants of the appraisal of cubist paintings. Brit. J. Psychol. 81:483-495, doi: 10.1111/ j.2044-8295.1990.tb02374.x.

Huang, L.C. 2007. Behavioral differences in prepurchase processes between purchasers of flowers for self use and for gift use. HortTechnology 17:183-190, doi: 10.21273/HORTTECH.17.2.183.

Hula, M. and J. Flegr. 2016. What flowers do we like? The influence of shape and color on the rating of flower beauty. PeerJ 4:e2106, doi: 10.7717/peerj.2106.

Hutchison, N.R. and J.L. Robertson. 1979. Consumer demand for roses. J. Amer. Soc. Hort. Sci. 104:303-308.

IBISWorld. 2019. Florists in the U.S. 23 Jan. 2020. <https://my.ibisworld.com/ download/us/en/industry/1096/1/0/ pdf>.

Jacobsen, T. and L. Hofel. 2002. Aesthetic judgments of novel graphic patterns: Analyses of individual judgments. Percept. Mot. Skills 95:755-766, doi: 10.2466/pms.2002.95.3.755.

Jacobsen, T., R.I. Schubotz, L. Hofel, and D. Cramon. 2006. Brain correlates of aesthetic judgment of beauty. Neuroimage 29:276-285, doi: 10.1016/j.neuroimage.2005.07.010.

Johnson, J.L., W.J. McKinley, and M. Benz. 2001. Flowers: Creative design. San Jacinto Publ., San Jacinto, CA.

Kelley, K.M., B.K. Behe, J.A. Biernbaum, and K.L. Poff. 2002. Combinations of colors and species of containerized edible flowers: Effect on consumer preferences. HortScience 37:218-221, doi: 10.21273/ HORTSCI.37.1.218.

Krejcie, R.V. and D. Morgan. 1970. Determining sample size for research activities. 
Educ. Psychol. Meas. 30:607-610, doi: $10.1177 / 001316447003000308$.

Kim, H.H., Y.J. Kyung, K. Ohkawa, C.H. Pak, and B.H. Kwack. 1999. Flower industry in Korea. Acta Hort. 482:407414.

Lai, Y. and L. Huang. 2013. The effect of relationship characteristics on buying fresh flowers as romantic Valentine's Day gifts. HortTechnology 23:28-37, doi: 10.21273/HORTTECH.23.1.28.

Leder, H., B. Belke, A. Oeberst, and D. Augustin. 2004. A model of aesthetic appreciation and aesthetic judgements. Brit. J. Psychol. 95:489-508, doi: 10.1348/ 0007126042369811.

Leder, H., P.P. Tinio, and M. Bar. 2011. Emotional valence modulates the preference for curved objects. Perception 40:649-655, doi: 10.1348/0007126042369811.

Likert, R. 1932. A technique for the measurement of attitudes. Arch. Psychol. 22:140-155.

Little, A.C. and B.C. Jones. 2003. Evidence against perceptual bias views for symmetry preferences in human faces. Proc. R. Soc. Lond. B Biol. Sci. 270:17591763, doi: 10.1098/rspb.2003.2445.

Loyola, C.E., J.M. Dole, and R. Dunning. 2019. North American specialty cut flower production and postharvest survey. HortTechnology 29:338-359, doi: 10.21273/ HORTTECH04270-19.

Mason, S., T. Starman, R.D. Lineberger, and B.K. Behe. 2008. Consumer preferences for price, color harmony and care information of container gardens. HortScience 43:380-384, doi: 10.21273/ HORTSCI.43.2.380.

National Rose Garden. 2020. The national flower. 25 Aug. 2020. <http:// nationalrosegarden.com/the-nationalflower $/>$.

Palma, M.A. and R.W. Ward. 2010. Measuring demand factors influencing market penetration and buying frequency for flowers in the US. Intl. Food Agribus. Mgt. Rev. 13:65-82.

Reber, R., N. Schwarz, and P. Winkielman. 2004. Processing fluency and aesthetic pleasure: Is beauty in the perceiver's processing experience? Pers. Soc. Psychol. Rev. 8:364-382, doi: 10.1207/ s15327957pspr0804_3.

Rihn, A.L., C. Yue, B. Behe, and C. Hall. 2011. Generations X and Y attitudes toward fresh flowers as gifts: Implications for the floral industry. HortScience 46:736-743, doi: 10.21273/HORTSCI. 46.5.736.

Rihn, A.L., C. Yue, C. Hall, and B. Behe. 2014. Consumer preferences for longevity information and guarantees on cut flower arrangements. HortScience 49: 769-778, doi: 10.21273/HORTSCI.49. 6.769 .

Rihn, A., H. Khachatryan, B. Campbell, C. Hall, and B. Behe. 2016. Consumer preferences for organic production methods and origin promotions on ornamental plants: Evidence from eye-tracking experiments. Agr. Econ. 47:599-608, doi: 10.1111 /agec.12258.

Robinson, J., C. Rosenzweig, A.J. Moss, and L. Litman. 2019. Tapped out or barely tapped? Recommendations for how to harness the vast and largely unused potential of the Mechanical Turk participant pool. PLoS One 14:E0226394, doi: 10.1371/journal.pone.0226394.

Rombach, M., N. Widmar, E. Byrd, and V. Bitsch. 2018. Understanding preferences of German flower consumers: The desire for sustained beauty. Intl. J. Retail Distrib. Manag. 46:560-576, doi: 10.1108/ IJRDM-10-2017-0229.

Silvia, P.J. and C.M. Barona. 2009. Do people prefer curved objects? Angularity, expertise, and aesthetic preference. Empir. Stud. Arts 27:25-42, doi: 10.2190/ EM.27.1.b.

Tavakol, M. and R. Dennick. 2011. Making sense of Cronbach's alpha. Intl. J. Med. Educ. 2:53-55, doi: 10.5116/ ijme. $4 \mathrm{dfb} .8 \mathrm{dfd}$.

Tinio, P.P. and H. Leder. 2009. Just how stable are stable aesthetic features? Symmetry, complexity, and the jaws of massive familiarization. Acta Psychol. 130:241250, doi: 10.1016/j.actpsy.2009.01.001.
U.S. Department of Agriculture. 2019. Floriculture crops 2018 summary. 12 Jan. 2020. <https://www.nass.usda.gov/ Publications/Todays_Reports/reports/ floran 19.pdf>.

U.S. Department of Agriculture. 2020. Reports. 1 Sept. 2020. <https://www. ams.usda.gov/mnreports/wa_fv281. txt>.

VanDerZanden, A.M., D. Sandrock, and D. Kopsell. 2008. Student attitudes and perceptions of an online problem-based learning case study in landscape management. HortTechnology 18:520-523, doi: 10.21273/HORTTECH.18.3.520.

Vierheilig, B.M. and R.V. Alvensleben. 1986. Positioning cut flowers in the perception and preference space of the consumer. Hort. Econ. Newsletter, Netherlands 36:17-28.

Vierheilig, B.M. and R.V. Alvensleben. 1988. Positioning cut flowers in the perception and preference space of the consumers - New results. Acta Hort. 223:345-349, doi: 10.17660/ActaHortic.1988.223.55.

Weberling, F. 1992. Morphology of flowers and inflorescences. Cambridge Univ. Press, Cambridge, UK.

Westerman, S.J., P.H. Gardner, E.J. Sutherland, T. White, K. Jordan, D. Watts, and S. Wells. 2012. Product design: Preference for rounded versus angular design elements. Psychol. Mktg. 29:595-605, doi: 10.1002/mar.20546.

Yeh, T.F. and L.C. Huang. 2009. An analysis of floral consumption values and their difference for genders and geographic regions. HortTechnology 19:101-107, doi: 10.21273/HORTSCI.19.1.101.

Yue, C. and B.K. Behe. 2008. Estimating U.S. consumers' choice of floral retail outlets. HortScience 43:764-769, doi: 10.21273/HORTSCI.43.3.764.

Yue, C. and C. Hall. 2010. Traditional or specialty cut flowers? Estimating U.S. consumers' choice of cut flowers at noncalendar occasions. HortScience 45:382386, doi: 10.21273/HORTSCI.45.3.382. 